\title{
Determination of Underground Mineable Reserve with Regard to Metal Price Uncertainty and Sustainable Development
}

\author{
Somaye Narrei $^{(}$, Majid Ataee-pour $^{*}$ \\ Department of Mining and Metallurgical Engineering, Amirkabir University of Technology, Tehran, Iran \\ E-mail: map60@aut.ac.ir
}

Received: 27 September 2020; Revised: 20 December 2020; Accepted: 26 March 2021

\begin{abstract}
Mineable reserve determination is one of the important parameters in economic profitability and the safety of underground mining production. The fluctuations in the metal prices will lead to a change in the cut-off grade, and as a result, the mine layout and mineable reserve will change. On the other hand, changing the underground mine layouts will also change the economic, social and environmental impacts (sustainable development parameters). Therefore, ignoring metal price uncertainty lead to a non-optimal design. The aim of this paper is the determination of underground mineable reserve regarding metal price uncertainty and sustainable development. Metal price uncertainty is simulated with Monte Carlo technique and the most important sustainable development indicators are entered in the cut-off grade formula. In this way, four types of cut-off grades were defined. Based on these cut-offs four types of mine layouts are obtained. Basic, simulated, green and sustainable mine layout. Basic Mine layout is that obtained by normal design, simulated mine layout considers just metal price uncertainty, green mine layout considers metal price uncertainty and environmental criteria and sustainable mine layout considers metal price uncertainty and environmental and social criteria. Results from the use of this methodology in a hypothetical gold mine show that the mineable reserve in sustainable mine layout is 17 percent greater than the basic mine layout. Regarding the result, with this methodology in addition to consideration of metal price uncertainty and sustainable development criteria, the more mineable reserve will be achieved. For future research, in addition to using other price simulation methods; it is suggested that other indicators of sustainable development be included in determining the underground mine layout.
\end{abstract}

Keywords: underground mineable reserve, metal price uncertainty, sustainable development

JEL Codes: Q310

\section{Introduction}

Determination of mining limits for each of open pit and underground is one of the most significant parts that impacts the economic aspects of a mining operation. There are few algorithms for determination of this area such as floating stope algorithm developed by Alford. Mineable Reserves Optimization (MRO) is a set of scripts in Datamine software for determination of mine layout in underground mines, based on floating stope algorithm. MRO analyzes a geological model and delineates optimal mineable reserves using practical mining constraints. It creates and evaluates

Copyright (C2021 Majid Ataee-pour, et al.

DOI: https://doi.org/10.37256/ges.222021676

This is an open-access article distributed under a CC BY license

(Creative Commons Attribution 4.0 International License)

https://creativecommons.org/licenses/by/4.0/ 
three-dimensional envelopes of material considering factors such as the minimum size, shape and orientation of the mining units, and the minimum head grade of the mined material (CAE., n.d.).

The main input data in determining the mine layout is a set of block information. Each of these blocks has a certain grade and economic value. The cut-off grade and economic value of each block are calculated using metal prices, total recovery of extraction and processing operations, and extraction and processing costs. The fluctuations in the metal prices will lead to a change in the cut-off grade and economic value of the blocks, and as a result, the mine layout and mineable reserve will change. On the other hand, considering the life of mines, which is usually between 20 to 30 years, as well as price changes during the life of the mine, choosing the accurate price in the initial design and review plans is very important. Accordingly metal price is one of the most important parameters in determining the underground mine layouts. On the other hand, changing the underground mine layouts will also change the economic, social and environmental impacts.

Numerous research works have been carried out for price uncertainty and its effect on mining projects but none of them considered in underground mine layout. This also applies to sustainable development. Ignoring metal price uncertainty and sustainable development parameters in the mine design lead to a non-optimal design. Simultaneous consideration of metal price uncertainty and sustainable development criteria is one of the research innovations. In the MRO script, cut-off grade is one of the parameters that is entered by the user. In this research, cut-off grade distribution was obtained based on metal price distribution and with Monte Carlo methodology. In addition to economic and environmental criteria, this research has paid attention to social criteria. Environmental criteria include the cost and income of mine reclamation. Social criteria include the cost of workforce training and the value of created jobs. Sustainable development indicators have been quantified and entered in the cut-off grade formula. Accordingly, four types of cut-off grades were defined. Based on these cut-off grades and with maximization of grade optimization method; four types of mine layouts were obtained. This methodology has been used in a hypothetical gold mine and the results were described.

\section{Literature review}

Kim (1978) described the various optimization techniques for mine limits determination. The underground mine layout indicates the area for mineable reserve. However, only a few algorithms have been developed for optimizing final stope limits in underground mining. Reviews of these algorithms may be found in (Ataee-pour, 2005; Nhleko et al., 2018).

Economic uncertainty is one of the most important sources of uncertainty, which has a critical impact on the mine project evaluation. Many researchers studied these types of uncertainties (Dowd, 1976; Dimitrakopoulos et al., 2002; Godoy \& Dimitrakopoulos, 2004; Rendu, 2006; Dimitrakopoulos et al., 2007; Dimitrakopoulos et al., 2008; Else \& Curwen, 2006; Taylor et al., 2012; Fanning \& Parekh, 2004; MacAvoy, 1988). Economic uncertainty can have the greatest impact on the value of a mining project in the form of three sources of uncertainty: price and income, operating and capital costs, and discount rates. From the economic point of view, future metal prices are the most important factors of economic uncertainty. Numerous research works have been carried out for price uncertainty (Michael \& Schwartz, 1985; Trigeorgis, 1993; Moyen et al., 1996; Kelly, 1998; Moel \& Tufano, 2002; Optimisation, 2005; Samis et al., 2005; Shafiee et al., 2009). No reports have yet been made of the invention of a successful prediction of price and what makes the price uncertain is the weakness of the price prediction methods. But in any case, even with efficient methods of forecasting, the forecast is erroneous and creates a degree of uncertainty. Further studies have been carried out on price uncertainty in various mining issues (McIsaac, 2008; Castillo \& Dimitrakopoulos, 2014; Salama et al., 2015; Dehghani \& Ataee-pour, 2011; Dehghani \& Shirkavand, 2014). None of the researches considered the effect of price uncertainty in underground mine layout which is the goal of this paper.

Sustainable development consists of economic, environmental, and social criteria (Nathanail \& Bardos, 2005). Mining operations are extracting nonrenewable minerals. Therefore, reserve efficiency is one of the factors in any sustainable mine design (James, 1999). The concept of sustainability and sustainable development has been successfully extended to mining, but there have been few attempts to consider all three criteria. In recent years, several studies have focused on the issue of sustainable development in mining. In 2001, a model for stripping was proposed to minimize 
reclamation costs, reducing the cost of construction of the waste dump and flattening the mined land at the end of the mine life (Caccetta \& Kelsey, 2001). Two studies have also been conducted on production planning and sustainable development (Burgher \& Erickson, 1984; Ersan et al., 2003). The block model is another one that has been investigated in this regard (Botín, 2013; Rahmanpour \& Osanloo, 2013). Most of the researches consider the two aspects of the economy and the environment from the principles of sustainable development. A few numbers of studies considered the third principle. These studies fall into two categories. The first category includes the design and evaluation of mining (Odell, 2004). In the second category, the progress of research in determining the ultimate mine layout in terms of sustainable development criteria has been studied (Craynon et al., 2012; Xu et al., 2014; Adibi et al., 2015). A review of studies on sustainable development in mining may be found in (Asr et al., 2019; Gorman \& Dzombak, 2018). Limited researches are about quantifying the sustainable development attributes (Amirshenava \& Osanloo, 2019; Fernandes de et al., 2017). In addition, the limited research that addresses all three principles of sustainable development in mining is not about determining underground mine layout.

Given the multiplicity of attributes related to sustainable development, the selection of the most important attributes in each criterion is important. The indicators given in this article have been selected based on literature review. Some research on mining and sustainable development is given in Table 1. In this study, based on group discussions, interviews with experts and specialists in sustainable development, the most important quantitative attributes have been selected. These attributes include the cost and revenue of reclamation, the cost of staff training and the value of the created job.

Table 1. Mining characteristics studied in various references

\begin{tabular}{cc}
\hline Attribute & Reference \\
\hline Ivanova et al., 2007; Ivanova and Rolfe, 2011; Boateng and Awuah-Offei, 2017; \\
Employment & Que, 2015; Que et al., 2015; Gillespie and Kragt, 2012; Veiga et al., 2001; Azapagic, 2004; \\
Hajkowicz et al., 2011; Jul-Larsen et al., 2006; Petrova and Marinova, 2013; Franks, 2012; \\
Lockie et al., 2009; Hilson, 2002; Weldegiorgis and Ali, 2016; \\
Martin et al., 2007; Ejdemo and Söderholm, 2011; Aragón and Rud, 2013 \\
Que, 2015; Que et al., 2015; Boateng and Awuah-Offei, 2017; Que et al., 2016 \& 2018; \\
Azapagic, 2004; Veiga et al., 2001; Hajkowicz et al., 2011; Jul-Larsen et al., 2006; Franks, 2012; \\
Weldegiorgis and Ali, 2016; Martin et al., 2007; Ejdemo and Söderholm, 2011; \\
Aragón and Rud, 2013; Kitula, 2006; Gordon, 2003; \\
Bice, 2016; Esteves, 2008; Tonts et al., 2012; Damigos and Kaliampakos, 2006 \\
Ivanova et al., 2007; Gillespie and Kragt, 2012; Que et al., 2016 \& 2018; Azapagic, 2004; \\
Lockie et al., 2009; Hilson, 2002; Martin et al., 2007; \\
Ejdemo and Söderholm, 2011; Aragón and Rud, 2013 \\
\hline
\end{tabular}

\section{Methodology}

The aim of this paper is the determination of underground mine layout regarding sustainable development. Therefore, sustainable development indicators must be affected by one of the software inputs. This paper uses cut-off grade for this purpose. In the MRO script, the cut-off grade is one of the cases that is determined by the user. Metal price uncertainty is simulated by the Monte Carlo method. The cut-off grade is modeled, and its variables are costs and incomes. Metal price is one of the variables with a special distribution that is simulated by the Monte Carlo method. This is done by @RISK software. Three attributes of social principal and two attributes of environmental principal quantified. Social attributes include the cost of training of the workforce and the value of created jobs. Environmental attributes include the cost and income of reclamation. These quantified attributes have been entered in the formulation of the cut-off grade. In this way, four types of cut-off grade are defined as:

1. Basic Cut-off Grade (BCG): Price uncertainty and sustainable development not considered.

2. Simulated Cut-off Grade (SimCG): Only price uncertainty considered.

3. Green Cut-off Grade (GCG): Price uncertainty and environmental indicators of sustainable development 
considered.

4. Sustainable Cut-off Grade (SusCG): Price uncertainty, environmental and social indicators of sustainable development considered.

The cut-off grade formula of each scenario is as follows:

$$
\begin{gathered}
B C G=\frac{b+c}{y(p-s)} \\
\operatorname{Sim} C G=\frac{b+c}{y(d t b(p)-s)} \\
G C G=\frac{b+c+R_{C}-R_{I}}{y(d t b(p)-s)} \\
\operatorname{Sus} C G=\frac{b+c+R_{C}-R_{I}+T_{C}-E_{V}}{y(d t b(p)-s)}
\end{gathered}
$$

Notations of the above equations are defined in below:

$b$ : Extraction cost $(\$ /$ ton $)$

$c$ : Processing cost (\$/ton of ore)

$y$ : Recovery (\%)

$p$ : Metal price $(\$ /$ ton $)$

$d t b(p)$ : Distribution of metal prices

$s$ : Selling cost (\$/ton of metal)

$R_{C}:$ Reclamation cost (\$/ton of ore)

$R_{I}$ : Reclamation income (\$/ton of ore)

$T_{C}$ : Training cost $(\$ /$ ton of ore)

$E_{V}$ : Employment value (\$/ton of ore)

In equations (3) and (4), the cost parameters (reclamation and training costs) were added to the numerator because more costs lead to lower cut-off grades. In these equations, the revenue parameters (reclamation income and created job values) were deducted from the numerator because more income leads to higher cut-off grade. In equations (2) to (4), price distribution placed in the denominator instead of a fixed number of metal prices. Each simulation time, a price is randomly selected from the distribution (by software and based on the Monte Carlo technique) and the cut-off grade is calculated according to equations (2) to (4).

Based on these cut-off grades and with maximization of grade optimization method; different types of mine layouts are obtained, which are Basic Mine Layout (BML), Simulated Mine Layout (SimML), Green Mine Layout (GML), Sustainable Mine Layout (SusML). The steps to use this method are as follows:

Step 1: Find the metal prices in previous years.

Step 2: Find the best distribution function of metal price.

Step 3: Find effective attributes of sustainable development.

Step 4: Quantify sustainable development attributes.

Step 5: Calculate basic cut-off grade.

Step 6: Update basic cut-off grade formula with quantified sustainable development attributes.

Step 7: Set numerical value of each parameter.

Step 8: Set price distribution function Instead of metal price.

Step 9: Simulate the cut-off grades.

Step 10: Find ultimate mine layout with cut-off grade of previous section. 
Step 11: Select the optimum underground mine layout.

\section{Result and discussion}

This section illustrates the application and results of the mentioned approach in a small hypothetical underground gold mine as a case study. Using a density of 2.5 the total tonnage of ore is $3.08 \mathrm{mt}$ at $1.23 \mathrm{~g} / \mathrm{t} \mathrm{Au}$. Reserves have been calculated for Au cut-offs between 0 and $3 \mathrm{~g} / \mathrm{t}$ at intervals of $0.25 \mathrm{~g} / \mathrm{t}$. The resulting grade and tones above each of the 13 cut-offs are shown in Figure 1.

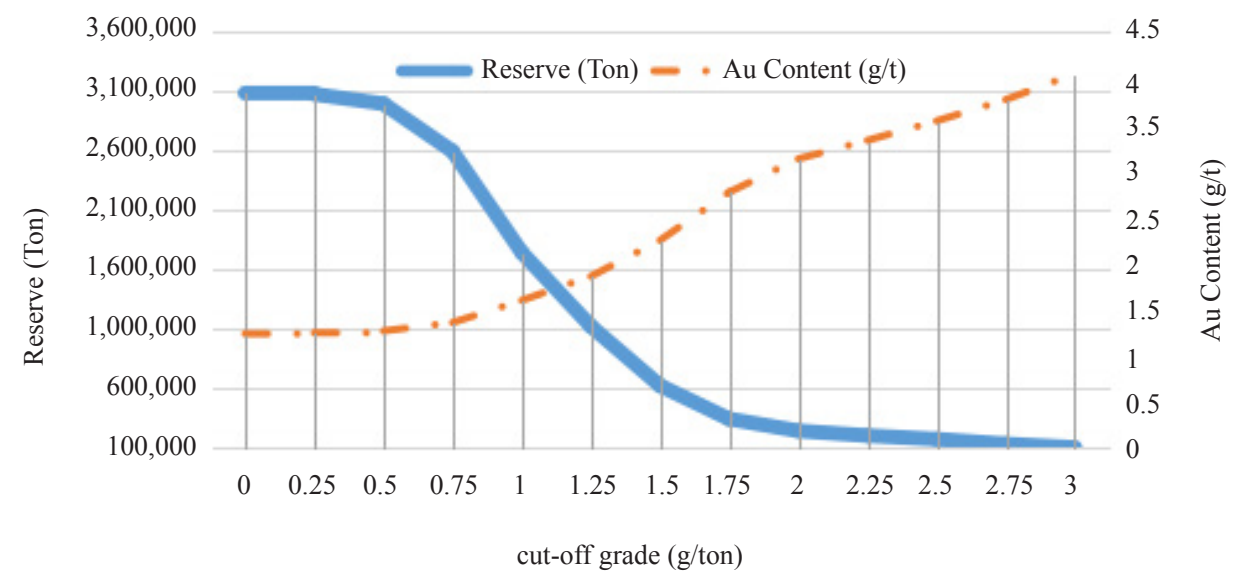

Figure 1. Resulting grade and tones above each of the cutoffs

This mine is extracted by cut and fill method. The processing method is leaching. Based on the Taylor formula for production rate, the mine life is about 8 years. Training costs and employment value of 150 people over 8 years of the mine life is calculated. Reclamation plan is the construction of the mining museum and tourism complex. Reclamation benefits include income from the tourist attraction and employment value of 50 people for 50 years. Regarding the importance of employment, the value of creating any job is assumed equivalent to the basic salary. All costs and incomes discounted to the beginning of the mine production and divided to $3.08 \mathrm{mt}$. These items and other notations of the case study introduced in Table 2. Figure 2 shows costs and revenues.

Table 2. The notations of the case study

\begin{tabular}{cccc}
\hline Notation & Explanation & Unit & Case study \\
\hline$b$ & Extraction costs & \$/ton of ore & 55 \\
$\mathrm{c}$ & Processing costs & \$/ton of ore & 28 \\
$\mathrm{y}$ & Recovery & $\%$ & 80 \\
$\mathrm{~s}$ & Selling costs & \$/ton of metal & $2,000,000$ \\
$R_{C}$ & Cost of reclamation & \$/ton of ore & 0.33 \\
$\mathrm{R}_{\mathrm{I}}$ & Income of reclamation & \$/ton of ore & 0.31 \\
$\mathrm{~T}_{\mathrm{C}}$ & Cost of training & \$/ton of ore & 0.05 \\
$\mathrm{E}_{\mathrm{V}}$ & Value of employment & \$/ton of ore & 1.14 \\
\hline
\end{tabular}




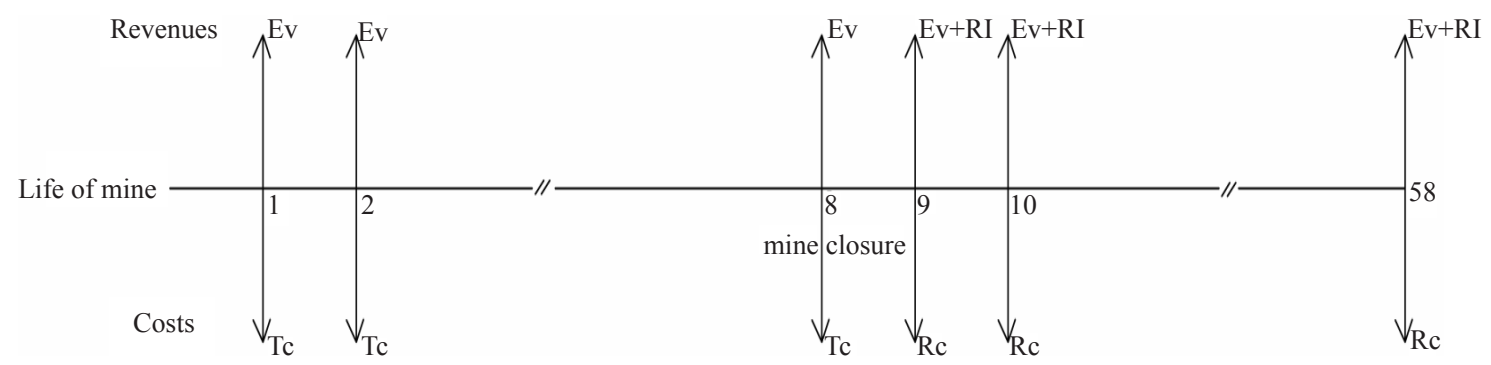

Figure 2. Sustainable development costs over the life of the mine

Monthly gold price changes over past 3 years shows the price of gold was downgraded since the middle of 2014 to early 2016, but this trend is set to rise in 2016, and it slowed down again at the end of 2016 and early 2017 (Figure 3).

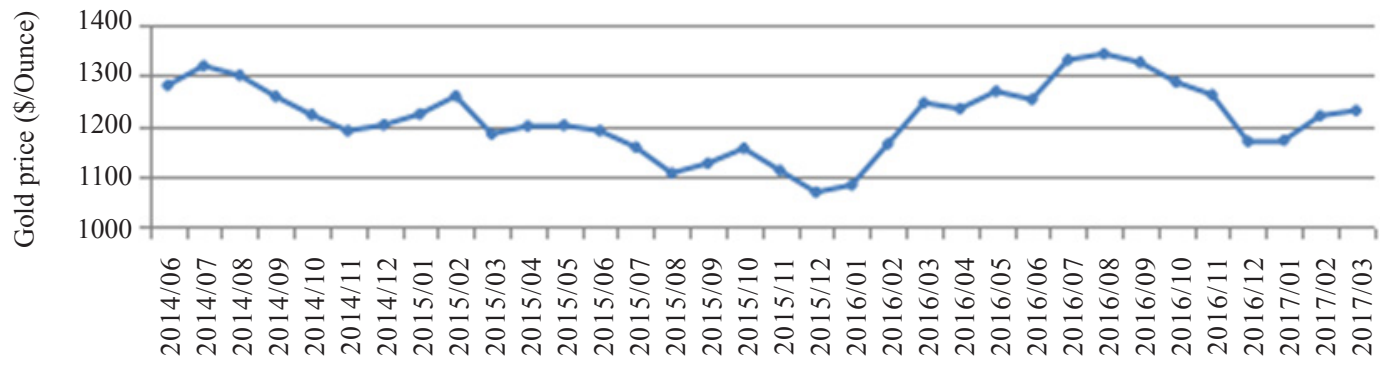

Date

Figure 3. Monthly gold price changes over past 3 years (Gold Price, n.d.)

Other cut-off grades mentioned in the previous section calculate based on the distribution of gold price changes. Table 3 shows summary information of this modeling. Inputs are gold price distribution in 3 outputs include SimCG, GCG and SusCG. Statistics of inputs and outputs are in Table 3. Monte Carlo method has been randomly sampled from gold price data. According to Table 3, the maximum, the mean and the minimum random prices for each grade. Given the inverse relationship between the price of metal and the grade, it is expected that the maximum price will be the lowest limit, which will be verified according to the table.

Table 3. Statistics of inputs and outputs of modeling with @RISK

\begin{tabular}{cccc} 
& \multicolumn{2}{c}{ Input (gold price (\$/Ounce) $)$} & \\
Name & Minimum & Mean & Maximum \\
Price for SimCG & 414.9 & 513.9 & 716.0 \\
Price for GCG & 371.9 & 510.6 & 606.5 \\
Price for SusCG & 373.0 & 512.4 & 639.0 \\
\hline Name & Output (cut-off grades $(\mathrm{ppm}))$ & \\
SimCG & Minimum & Mean & 3.5 \\
GCG & 1.9 & 2.8 & 3.9 \\
SusCG & 2.3 & 2.8 & 3.9 \\
\hline
\end{tabular}


After simulating each cut-off grade, the cut-off grade is obtained by counting the number of times simulated. In the next step, it must be determined to compare the defined cut-off grade, which of the calculated cut-off grades should be considered. In this article; the minimum, maximum and average of the range in which $90 \%$ of the simulated cutoff grades are compared. Figure 4 shows the histogram for outputs. Accordingly, possibly $90 \%$, the lower limit of the simulated, green and sustainable cut-off grade is $2.5 \mathrm{ppm}$.

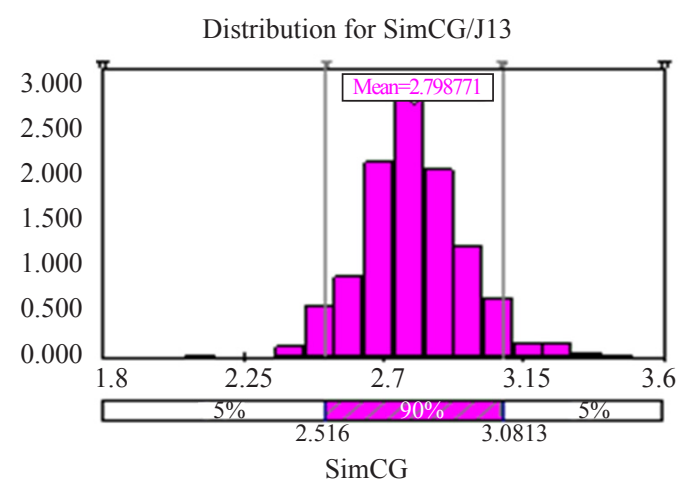

Distribution for GCG/L13
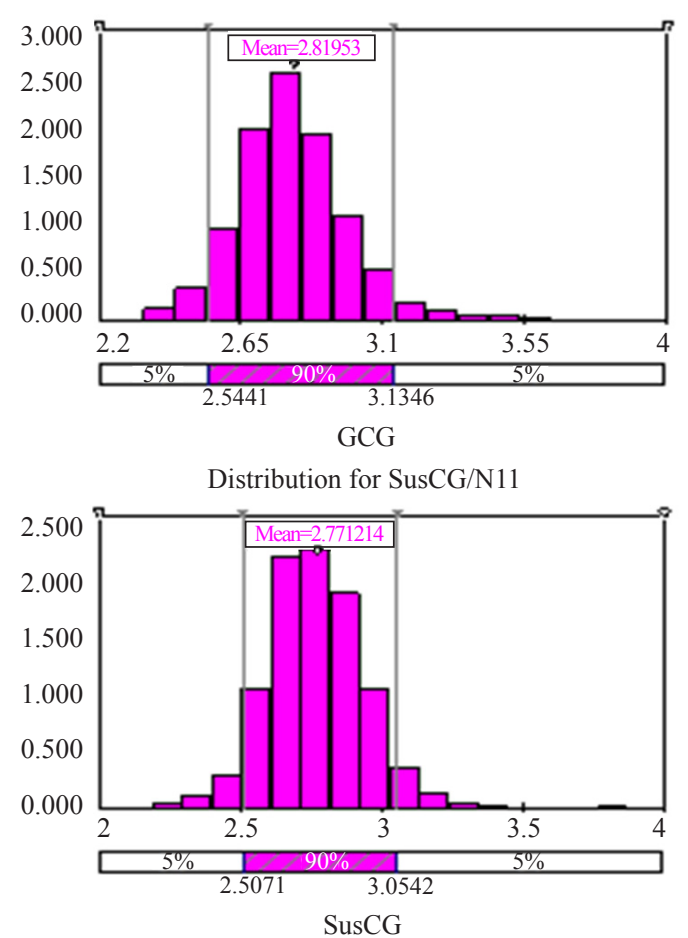

Figure 4. histogram of Cut-off Grades

Table 4. Upper and lower limit of defined cut-off grades

\begin{tabular}{ccc}
\hline Cut-off Grade & $\begin{array}{c}\text { Lower Limit of Cut-off Grade (LLCG) } \\
(\mathrm{ppm})\end{array}$ & $\begin{array}{c}\text { Upper Limit of Cut-off Grade (ULCG) } \\
(\mathrm{ppm})\end{array}$ \\
\hline BCG & 2.8 & 2.8 \\
SimCG & 2.5 & 3.1 \\
GCG & 2.5 & 3.1 \\
SusCG & 2.5 & 3 \\
\hline
\end{tabular}


The upper limit of these cut-off grades is 3.1 and 3 ppm respectively. As you can see BCG (2.8 ppm) is between the lower and upper limit of SimCG and SusCG. A summary of the various cut-off grades given in Table 4.

With these different cut-off grades, Data mine software was used to obtain the corresponding mineable reserve. One of the features of MRO is the ability to handle sensitivity analyses. Each run of the Optimizer is defined as a case which has a user-defined case name, with all parameters for each case being stored and retrieved automatically. This makes it simple to run and compare alternative scenarios for factors such as cut-off grade, head grade and mining methods. Specifications of these cases are given in Table 5.

Table 5. Mineable reserves optimizer-multi-case report

\begin{tabular}{|c|c|c|c|c|c|c|}
\hline Case & Envelope type & Volume $\left(\mathrm{M}^{3}\right)$ & Tonnes & $\mathrm{AU}(\mathrm{ppm})$ & Cut-off grade (ppm) & Number of envelopes \\
\hline \multirow{2}{*}{ Run A } & Geology & 97,840 & 244,600 & 3.12 & 2 & - \\
\hline & Min-Mod & 60,500 & 151,250 & 3.159 & 2 & 3 \\
\hline \multirow{2}{*}{ Run B } & Geology & 66,880 & 167,200 & 3.525 & 2.5 & - \\
\hline & Min-Mod & 54,000 & 135,000 & 3.292 & 2.5 & 2 \\
\hline \multirow{2}{*}{ Run C } & Geology & 49,192 & 122,980 & 3.835 & 2.8 & - \\
\hline & Min-Mod & 46,000 & 115,000 & 3.492 & 2.8 & 2 \\
\hline \multirow{2}{*}{ Run D } & Geology & 40,416 & 101,040 & 4.038 & 3 & - \\
\hline & Min-Mod & 37,500 & 93,750 & 3.745 & 3 & 1 \\
\hline \multirow{2}{*}{ Run E } & Geology & 36,056 & 90,140 & 4.156 & 3.1 & - \\
\hline & Min-Mod & 34,500 & 86,250 & 3.845 & 3.1 & 1 \\
\hline $\begin{array}{l}\operatorname{Run} A= \\
\operatorname{Run} B= \\
\operatorname{Run} C= \\
\text { Run } D= \\
\text { Run } E=\end{array}$ & $\begin{array}{l}\text { t-off grade is equa } \\
\text { t-off grade is equ } \\
\text { t-off grade is equ } \\
\text { t-off grade is equ } \\
\text { t-off grade is equ }\end{array}$ & $\begin{array}{l}\text { head grade }=2 \\
\text { lower limit of } \\
\mathrm{BCG}=2.8 \mathrm{pp} \\
\text { upper limit of } \\
\text { upper limit of }\end{array}$ & $\begin{array}{l}\mathrm{G}, \mathrm{GCG} \text { a } \\
\mathrm{S}=3 \mathrm{ppm} \\
\text { and } \mathrm{SusC}\end{array}$ & $\mathrm{usCG}=2.5 \mathrm{p}$ & & \\
\hline
\end{tabular}

For each run, the geological and mineable reserves are available. Contiguous blocks are grouped into mineable envelopes and assigned an envelope number. With increasing cut-off grade mineable reserve, the number of envelopes decreases. Given the inverse relationship between the cut-off grade and mine layout, the upper limit of cut-off grades gives the lower limit of mine layout and vice versa. In Table 6, the upper and lower limits of the defined layouts are given. As you can see, the largest possible for all three simulated, green and sustainable ones is the same, but the smallest possible layout varies depending on the cut-off grades.

Table 6. The upper and lower limit of determined mine layouts

\begin{tabular}{ccc}
\hline Mine layout & Upper Limit of Mine Layout (ULML) (ton) & Lower Limit of Mine Layout (LLML) (ton) \\
\hline BML & 115,000 & 115,000 \\
SimML & 135,000 & 86,250 \\
GML & 135,000 & 86,250 \\
SusML & 135,000 & 93,750 \\
\hline
\end{tabular}

The difference between the upper limit of extraction is 17 percent. The maximum difference of the lower limit is between basic, simulated and green cut-off grades, which is equal to 33 percent. If the goal is increasing the mine life and job creation, the optimum cut-off grade is close to the lower limit of cut-off grades. In this case, the optimum mine 
layout is close to the upper limit of simulated mine layout, green mine layout and sustainable mine layout (mineable reserve is equal to 135,000 ton). If the target is increasing the average grade of the mined material, the optimum cut-off grade should be close to the upper limit of the cut-off grades (3.1 gr/ton). In this way, the optimum mine layout is close to the lower limit of green mine layout and simulated mine layout (mineable reserve is equal to 86,250 ton).

\section{Conclusion}

In the mining industry, metal prices are normally modeled as the average price for the last three years. It may be misleading when evaluating mining projects. Meanwhile, mining operations are extracting nonrenewable minerals. Therefore, reserve efficiency is one of the factors in any sustainable mine design. This paper proposed a methodology for consideration of sustainable development criteria and metal price uncertainty in underground mine layout optimization. This study introduced four types of underground mine layouts, which are Basic Mine Layout (BML), Simulated Mine Layout (SimML), Green Mine Layout (GML), Sustainable Mine Layout (SusML). Results show that SusML which considers the metal price uncertainty and sustainable development criteria is 17 percent greater than BML. This method considers the uncertainty of metal price and sustainable development criteria with a larger mine layout which leads to longer mine life and social impacts of this. Quantifying a few sustainable development attributes was one of the limitations of this study. It is suggested to use various methods in economics to quantify qualitative attributes. Then, using the methodology described in this paper, determine the optimal underground mineable reserve based on sustainable development attributes.

\section{Reference}

Adibi, N., Ataee-Pour, M., \& Rahmanpour, M. (2015). Integration of sustainable development concepts in open pit mine design. Journal of Cleaner Production, 108, 1037-1049. https://doi.org/10.1016/j.jclepro.2015.07.150.

Amirshenava, S., \& Osanloo, M. (2019). A hybrid semi-quantitative approach for impact assessment of mining activities on sustainable development indexes. Journal of Cleaner Production, 218, 823-834. https://doi.org/10.1016/ j.jclepro.2019.02.026.

Aragón, F. M., \& Rud, J. P. (2013). Natural resources and local communities: Evidence from a peruvian gold mine. American Economic Journal: Economic Policy, 5(2), 1-25.

Asr, E. T., Kakaie R., Ataei, M., \& Mohammadi, M. R. T. (2019). A review of studies on sustainable development in mining life cycle. Journal of Cleaner Production, 229, 213-231. https://doi.org/10.1016/j.jclepro.2019.05.029.

Ataee-pour, M. (2005). A critical survey of the existing stope layout optimization techniques. Mining Science, 41(5), 447-466. https://doi.org/10.1007/s10913-006-0008-9.

Azapagic, A. (2004). Developing a framework for sustainable development indicators for the mining and minerals industry. Journal of Cleaner Production, 12(6), 639-662.

Bice, S. (2016). Responsible Mining: Key Principles for Industry Integrity. London: Routledge.

Boateng, M. K., \& Awuah-Offei, K. (2017). Agent-based modeling framework for modeling the effect of information diffusion on community acceptance of mining. Technological Forecasting and Social Change, 117, 1-11.

Botín, J. A. (2013). A methodology to integrate sustainable development performance in the mine design and planning process: A case study. 6th International Conference on Sustainable Development in the Minerals Industry, 30 June -3 July 2013. Milos Island, Greece.

Burgher, K. E., \& Erickson, E. (1984). The optimization of coal mine production schedules using linear programming: An example that determines the effects of reclamation costs and interest rates. Mining Science and Technology, 2(1), 69-78. https://doi.org/10.1016/S0167-9031(84)90223-8.

Caccetta, L., \& Kelsey P. J. (2001). Models for Mine Site Rehabilitation. International Congress on Modeling and Simulation.

CAE. (n.d.). Datamine Studio 3, User's Manual, Mineable Reserve Optimization Help.

Castillo, F. D., \& Dimitrakopoulos, R. (2014). Joint effect of commodity price and geological uncertainty over the life of mine and ultimate pit limit. Transactions of the Institutions of Mining and Metallurgy, Section A: Mining Technology, 123(4), 207-219. https://doi.org/10.1179/1743286314Y.0000000069.

Craynon, J., Karmis, M., \& Tech, V. (2012). Optimising coal mine design for sustainable development at large surface 
coal mining operations in appalachia. In Coal International, 260, 39-43.

Damigos, D., \& Kaliampakos, D. (2006). The 'battle of gold' under the light of green economics: A case study from Greece. Environmental Geology, 50(2), 202-218.

Dehghani, H., \& Ataee-pour, M. (2011). Determination of the economic value of the block under the conditions of economic uncertainty. In The First Conference of Iranian Mining Technologies.

Dehghani, H., \& Shirkavand, R. (2014). Evaluation of mineral projects under the impact of economic uncertainties using time series. In 5 'Th Mining Conference.

Dimitrakopoulos, R., Farrelly, C. T, \& Godoy, M. (2002). Moving forward from traditional optimization: grade uncertainty and risk effects in open-pit design. Mining Technology IMM Transactions Section A, 111, A82-A88.

Dimitrakopoulos, R., Martinez, L., \& Ramazan, S. (2007). A maximum upside/minimum downside approach to the traditional optimization of open pit mine design. Journal of Mining Science, 43(1), 73-82. https://doi.org/10.1007/ s10913-007-0009-3.

Dimitrakopoulos, R., Chou, C., \& Godoy, M. (2008). Resource/reserve classification with integrated geometric and local grade variability measures. In Cosmo 08, 131-154.

Dowd, P. (1976). Application of dynamic and stochastic programming to optimize cutoff grades and production rates. Transactions of the Institution of Mining and Metallurgy, Section A: Mining Technology, 85.

Ejdemo, T., \& Söderholm, P. (2011). Mining investment and regional development: A scenario-based assessment for Northern Sweden. Resources Policy, 36(1), 14-21.

Else, P., \& Curwen, P. (2006). Principles of Microeconomics (1st ed.). London: Routledge. https://doi. org/10.4324/9780203018002.

Ersan, H., Dagdelen K., \& Rozgonyi, T. (2003). Environmental issues and eco-based mine planning. In Proceeding of the 18th International Mining Congress and Exhibition of Turkey (IMCET) (pp. 11-17).

Esteves, A. M. (2008). Mining and social development: Refocusing community investment using multi-criteria decision analysis. Resources Policy, 33(1), 39-47.

Fanning, S., \& Parekh, J. (2004). Stochastic processes and their applications to mathematical finance. University of Maryland.

Fernandes de, M., Xavier, A., Klein, B., \& Matos, F. R. N. (2017). Mining and the sustainable development goals: A systematic literature review. Geo-Resources Environment and Engineering 2. https://doi.org/10.15273/ gree.2017.02.006.

Franks, D. (2012). Social Impact Assessment of Resource Projects. International Mining for Development Centre. https://www.im4dc.org/wp-content/uploads/2012/01/UWA_1698_Paper-02_Social-impact-assessment-of-resourceprojects1.pdf.

Gillespie, R., \& Kragt, M. E. (2012). Accounting for nonmarket impacts in a benefit-cost analysis of underground coal mining in New South Wales, Australia. Journal of Benefit-Cost Analysis, 3(2), 1-29.

Godoy, M., \& Dimitrakopoulos, R. (2004). Managing risk and waste mining in long-term production scheduling of open-pit mines. SME Transactions, 316(03), 43-50.

Gold Price. (n.d.). Available Online: Https://Goldprice.Org/

Gordon, R. L. (2003). Breaking new ground: mining, minerals and sustainable development. Resources Policy, 29(1-2), 69-70.

Gorman, M. R., \& Dzombak, D. A. (2018). A review of sustainable mining and resource management: Transitioning from the life cycle of the mine to the life cycle of the mineral. Resources, Conservation and Recycling, 137, 281291. https://doi.org/10.1016/j.resconrec.2018.06.001.

Hajkowicz, S. A., Heyenga, S., \& Moffat, K. (2011). The relationship between mining and socio-economic well being in Australia's regions. Resources Policy, 36(1), 30-38.

Hilson, G. (2002). An overview of land use conflicts in mining communities. Land Use Policy, 19(1), 65-73.

Ivanova, G., Rolfe, J., Lockie, S., \& Timmer,V. (2007). Assessing social and economic impacts associated with changes in the coal mining industry in the Bowen Basin, Queensland, Australia. Management of Environmental Quality: An International Journal, 18(2), 211-228.

Ivanova, G., \& Rolfe, J. (2011). Using input-output analysis to estimate the impact of a coal industry expansion on regional and local economies. Impact Assessment and Project Appraisal, 29(4), 277-288.

James, P. (1999). The Miner and Sustainable Development. 89-92.

Jul-Larsen, E., Kassibo, B., Lange, S., \& Samset, I. (2006). Socio-economic effects of gold mining in Mali: A study of the Sadiola and Morila mining operations. CMI Report, 2006(4), 1-71.

Kelly, S. (1998). A binomial lattice approach for valuing a mining property IPO. Quarterly Review of Economics and 
Finance 38(3 Part.1), 693-709.

Kim, Y. C. (1978). Ultimate pit limit design methodologies using computer models-the state of the art. Mining Engineering, 30(10), 1454-1459.

Kitula, A. G. N. (2006). The environmental and socio-economic impacts of mining on local livelihoods in Tanzania: A case study of Geita District. Journal of Cleaner Production, 14(3-4), 405-414.

Lockie, S., Franettovich, M., Petkova-Timmer, V., Rolfe, J., \& Ivanova, G. (2009). Coal mining and the resource community cycle: A longitudinal assessment of the social impacts of the Coppabella coal mine. Environmental Impact Assessment Review, 29(5), 330-339.

MacAvoy, P. W. (1988). Explaining Metal Prices: Economic Analysis of Markets in the 1980s and 1990s. Kluwer Academic, Boston.

Martin, S., Vettori, L., \& McLeod, J. (2007). Mining Ombudsman case report: Didipio gold and copper mine. Queen's University.

McIsaac, G. (2008). Strategic Design of an Underground Mine under Conditions of Metal Price Uncertainty. Queen's University.

Michael, J, B., \& Schwartz, S. E. (1985). Evaluating natural resource investments. The Journal of Business, $58(2)$, $135-$ 57.

Moel, A., \& Tufano, P. (2002). When are real options exercised? an empirical study of mine closings. Review of Financial Studies 15(1), 35-64. https://doi.org/10.1093/rfs/15.1.35.

Moyen, N., Slade, M., \& Uppal, R. (1996). Valuing risk and flexibility: A comparison of methods. Resources Policy, 22, 63-74.

Nathanail, C. P., \& Bardos, R. P. (2005). Reclamation of Contaminated Land. NY, U.S.: John Wiley \& Sons, Inc. https:// doi.org/10.1002/0470020954.

Nhleko, A. S., Tholana T., \& Neingo, P. N. (2018). A review of underground stope boundary optimization algorithms. Resources Policy 56, 59-69. https://doi.org/10.1016/j.resourpol.2017.12.004.

Odell, C. J. (2004). Integration of Sustainability into the Design Process. University of British Columbia. DOI: $10.14288 / 1.0081057$.

Optimisation, B. N. (2005). Beyond naive optimisation. In Spectrum, 14, 3-8.

Petrova, S., \& Marinova, D. (2013). Social impacts of mining: Changes within the local social landscape. Rural Society, 22(2), 153-165.

Que, S. (2015). Describing local community acceptance with discrete choice theory for enhanced community engagement. Phd Thesis, Missouri University of Science and Technology, Department of Mining and Nuclear Engineering. http://scholarsmine.mst.edu/doctoral dissertations/2416.

Que, S., Awuah-Offei, K., \& Samaranayake, V. A. (2015). Classifying critical factors that influence community acceptance of mining projects for discrete choice experiments in the United States. Journal of Cleaner Production, 87(1), 489-500. https://doi.org/10.1016/j.jclepro.2014.09.084.

Que, S., Awuah-Offei, K., Wang, L., Samaranayake, V. A., Weidner, N., \& Yuan, S. (2018). Individual preferences for mineral resource development: Perspectives from an urban population in the United States. Journal of Cleaner Production, 189, 30-39. https://doi.org/10.1016/j.jclepro.2018.04.045.

Que, S., Awuah-Offei, K., Weidner, N., \& Samaranayake, V. A. (2016). Mining stakeholder analysis using discrete choice theory: A case study in Salt Lake City. 2016 SME Annual Conference and Expo: The Future for Mining in a Data-Driven World, 324-327.

Rahmanpour, M., \& Osanloo, M. (2013). Application of a mathematical model to assess the sustainability of sungun copper mine. In 1st International Conference on Mining, Mineral Processing, Metallurgical and Environmental Engineering.

Rendu, J.-M. (2006). Reporting Mineral Resources and Mineral Reserves in the United States of America-Technical and Regulatory Issues (pp. 11-19). Australasian Institute of Mining and Metallurgy Publication Series.

Salama, A., Nehring, M., \& Greberg, J. (2015). Evaluation of the impact of commodity price change on mine plan of underground mining. International Journal of Mining Science and Technology, 25(3), 375-382. https://doi. org/10.1016/j.ijmst.2015.03.008.

Samis, M., Davis, G. A., Laughton, D., \& Poulin, R. (2005). Valuing uncertain asset cash flows when there are no options: A real options approach. Resources Policy, 30(4), 285-298. https://doi.org/10.1016/j.resourpol.2006.03.003.

Shafiee, S., Topal, E., \& Nehring, M. (2009). Adjusted real option valuation to maximise mining project value-A case study using century mine. Australasian Institute of Mining and Metallurgy Publication Series, 3, 125-134.

Taylor, J., Moosa, I., \& Cowling, B. (2012). Micro economics podcast. IEEE Internet Computing (pp. 93). IEEE. https:// 
doi.org/10.1109/mic.2012.113.

Tonts, M., Plummer, P., \& Lawrie, M. (2012). Socio-economic wellbeing in Australian mining towns: A comparative analysis. Journal of Rural Studies, 28(3), 288-301.

Trigeorgis, L. (1993). The nature of option interactions and the valuation of investments with multiple real options. The Journal of Financial and Quantitative Analysis, 28(1), 1. https://doi.org/10.2307/2331148.

Veiga, M. M., Scoble, M., \& McAllister, M. L. (2001).Mining with communities. Natural Resource Forum, 25(3), 191202.

Weldegiorgis, F. S., \& Ali, S. H. (2016). Mineral resources and localised development: Q-methodology for rapid assessment of socioeconomic impacts in Rwanda. Resources Policy, 49, 1-11.

Xu, X. C., Gu, X. W., Wang, Q., Liu, J. P., \& Wang, J. (2014). Ultimate pit optimization with ecological cost for open pit metal mines. Transactions of Nonferrous Metals Society of China (English Edition), 24(5), 1531-1537. https:// doi.org/10.1016/S1003-6326(14)63222-2. 